\title{
HUBUNGAN MINAT MEMBACA DENGAN KEMAMPUAN MEMBACA PEMAHAMAN SISWA KELAS X SMK YAPERJASA
}

\author{
Ida Rufaidah \\ Program Magister Pendidikan Bahasa Indonesia \\ Universitas Muhammadiyah Prof. Dr. Hamka \\ Jalan Limau II, RT.3/RW.3, Kramat Pela, Kecamantan Kebayoran Baru, Jakarta Selatan \\ Surel: idanadi96@gmail.com
}

\begin{abstract}
Abstrak
Penelitian ini bertujuan untuk menganalisis dan menginterpretasikan hubungan minat membaca dengan kemampuan membaca pemahaman mata pelajaran bahasa Indonesia siswa kelas X SMK Yaperjasa. Penelitian ini termasuk penelitian kuantitatif dengan metode survei dan teknik korelasional. Peneliti menentukan sampel dengan teknik simple random sampling. Sampelnya yaitu 50 siswa. Angket minat membaca berbentuk skala likert. Tes objektif kemampuan membaca pemahaman bertujuan untuk mengetahui kemampuan siswa dalam memahami sebuah wacana. Penelitian ini menunjukkan adanya hubungan positif dan signifikan antara minat membaca dengan kemampuan membaca pemahaman kelas X SMK Yaperjasa. Data minat membaca dan kemampuan membaca pemahaman berdistribusi normal. Hasil penelitian dibuktikan dengan hasil uji-t dan taraf signifikansi $\alpha=0,05$ diperoleh $_{\text {hitung }}=4,31$ dan $_{\text {tabel }}=1,677$. Hasilnya $t_{\text {hitung }}$ $\geq t_{\text {tabel }}$ atau 4,31 $\geq 1,677$ maka signifikan. Selanjutnya, uji hipotesis menggunakan korelasi Pearson Product Moment dengan koefisien korelasi 0,48. Hasil koefisien korelasi sebesar 0,48 berada pada tingkat sedang. Hasil dari uji determinasi menunjukkan bahwa pengaruh nilai minat membaca terhadap kemampuan membaca pemahaman sebesar $23 \%$ dan sisanya $77 \%$ dipengaruhi oleh variabel lain. Disimpulkan bahwa antara minat membaca dengan kemampuan membaca pemahaman atau pelajaran bahasa Indonesia siswa kelas X SMK Yaperjasa terdapat hubungan positif dan signifikan.
\end{abstract}

Kata kunci: Minat Membaca, Kemampuan Membaca Pemahaman.

\section{A. PENDAhULUAN}

Kegiatan berbahasa merupakan suatu kegiatan yang dilakukan oleh manusia untuk berkomunikasi dengan sesama dalam kehidupan sehari-hari. Pada saat melakukan kegiatan berbahasa, manusia juga dituntut untuk memiliki keterampilan berbahasa. Keterampilan dalam berbahasa diperlukan karena jika seseorang terampil dalam berbahasa maka semakin terarah dan jelas pemikirannya saat berbahasa. Selain itu, keterampilan berbahasa tidak dapat dipisahkan oleh dunia pendidikan.

Keterampilan berbahasa dalam pendidikan dapat dipelajari pada bidang pengajaran bahasa Indonesia. Terdapat empat keterampilan berbahasa yang harus dikuasai oleh siswa dalam pembelajaran di sekolah. Keterampilan tersebut antara lain keterampilan berbicara, menyimak, menulis, dan membaca. Salah satu keterampilan yang sangat penting untuk dimiliki oleh setiap siswa adalah keterampilan membaca.

Membaca merupakan suatu keterampilan berbahasa yang harus dikuasai oleh setiap siswa. Siswa akan mendapatkan ilmu dan informasi, mencakup isi, dan memaknai makna 
bacaan dari buku-buku yang ia baca. Selain itu, membaca juga dapat meningkatkan konsentrasi, daya ingat, memperkaya kosakata, dan melatih untuk berpikir analitis. Pada saat membaca sebuah buku atau suatu teks diperlukan kemampuan pemahaman bacaan sehingga maksud dan isi dari suatu teks dapat dimengerti dan dipahami dengan baik.

Kemampuan pemahaman seseorang terhadap isi suatu bacaan tentunya bermacammacam. Pemahaman seseorang terhadap suatu bacaan tentunya tidak terlepas dengan kegiatan membaca telaah isi. Pembaca harus menelaah dengan teliti isi dari suatu bacaan. Apabila siswa telah mampu menelaah isi bacaan maka ia dapat lebih mudah untuk menganalisis ataupun memahami makna suatu bacaan secara menyeluruh. Kemampuan membaca pemahaman seseorang sangat diperlukan karena akan berpengaruh pada hasil belajar siswa.

Penelitian sebelumnya yang dilakukan oleh Nurjanah (2012) tentang Hubungan antara Minat Baca dengan Hasil Belajar Bahasa Indonesia Siswa Kelas XI Sekolah Menengah Kejuruan Karya Wijaya Kusuma Jakarta Timur membuktikan bahwa ada hubungan signifikan atau minat membaca benar-benar berpengaruh dengan hasil belajar bahasa Indonesia siswa kelas XI Sekolah Menengah Kejuruan Karya Wijaya Kusuma Jakarta Timur.

Pemahaman seseorang tentunya memiliki hubungan dengan apakah seseorang memiliki minat membaca atau tidak terhadap buku atau suatu bacaan. Apabila seseorang sudah tidak memiliki minat untuk membaca maka akan merasa kesulitan dalam memahami isi bacaan. Namun, sebaliknya jika seseorang memiliki minat untuk membaca maka peluang untuk memahami keseluruhan isi bacaan menjadi lebih besar.

Peluang untuk memahami bacaan lebih besar karena dengan ia memiliki ketertarikan yang lebih tentunya ia akan lebih teliti. Selain itu, ia juga lebih bersungguh-sungguh dalam membaca. Melalui kesungguhannya dalam membaca maka pemahaman bacaan juga akan lebih baik. Hal ini menunjukkan bahwa minat membaca juga berhubungan dengan pemahaman bacaan.

Ketertarikan seseorang dalam membaca biasanya dipengaruhi oleh beberapa faktor. Faktor-faktor yang memengaruhi kemampuan dan minat membaca seseorang dapat diklasifikasikan menjadi dua kategori, yakni faktor yang bersifat intrinsik dan faktor yang bersifat ekstrinsik. Faktor intrinsik misalnya motivasi atau minat sedangkan faktor ekstrinsik misalnya keadaan lingkungan pada saat proses membaca. 
Seiring perkembangan zaman dan teknologi, seseorang semakin kurang memiliki minat untuk membaca hal-hal positif, seperti buku. Kurangnya minat membaca juga umumnya terjadi pada siswa. Siswa semakin kurang memiliki minat membaca buku-buku pelajaran. Saat ini, siswa lebih tertarik untuk bermain dengan gawai mereka daripada harus membaca buku-buku pelajaran.

Sekarang ini kesadaran siswa untuk membaca buku-buku yang berkaitan dengan sastra semakin berkurang. Kurangnya minat membaca siswa bisa berdampak pada kemampuan membaca pemahaman siswa terhadap suatu bacaan sastra. Siswa yang tidak memiliki kemampuan membaca pemahaman maka ia akan terkendala dalam menganalisis dan menjawab pertanyaan yang berkaitan dengan isi sebuah teks. Oleh karena itu, tidak dapat dimungkiri bahwa minat membaca siswa berkaitan dengan kemampuan membaca pemahaman seorang siswa.

Hasil observasi di kelas X SMK Yaperjasa menunjukkan bahwa minat membaca dan kemampuan membaca pemahaman siswa masih kurang. Hal ini terlihat dari siswa yang tidak membaca teks dengan teliti, tidak membaca dengan sungguh-sungguh teks yang sudah disediakan. Beberapa siswa tidak membaca kata atau kalimat dengan tepat, misalnya "keledai" dibaca "kedelai". Selain itu, beberapa siswa tidak memerhatikan dan mendengarkan siswa lain yang sedang membaca. Siswa juga kurang mampu menganalisis unsur-unsur sastra dan kurang tepat dalam menentukan makna tersirat dalam sebuah teks. Misalnya, banyak siswa yang kurang tepat dalam menentukan makna tersirat dari sebuah teks anekdot.

Beberapa siswa kelas X SMK Yaperjasa hanya sekilas membaca sebuah teks sehingga kurang bisa memahami isi bacaan. Siswa kurang bisa menjawab pertanyaan dengan tepat berkaitan dengan isi sebuah teks. Selain itu, siswa juga banyak yang tidak dapat menceritakan kembali isi sebuah teks.

Kurangnya minat membaca siswa juga disebabkan oleh keadaan lingkungan. Misalnya, seorang siswa sedang membaca sebuah teks anekdot tetapi teman sebangkunya mengajak berbicara sehingga siswa menjadi tidak tertarik untuk melanjutkan kegiatan membacanya. Hal ini menunjukkan bahwa tidak hanya faktor dari pembaca yang berpengaruh pada minat siswa untuk membaca tetapi faktor dari luar pembaca juga sangat berpengaruh. 
Guru Bahasa Indonesia kelas X SMK Yaperjasa menjelaskan bahwa minat baca siswa masih kurang. Penyebabnya adalah karena perkembangan teknologi yang menyebabkan siswa malas untuk membaca buku dan kreativitas siswa makin berkurang. Menurut guru bahasa Indonesia kelas X SMK Yaperjasa, kurangnya minat baca siswa berdampak pada nilai siswa saat mengerjakan soal-soal yang bersifat pemahaman. Rata-rata nilai yang didapat siswa adalah 78. Berdasarkan hal tersebut peneliti ingin melihat hubungan minat membaca dengan kemampuan membaca pemahaman Mata Pelajaran Bahasa Indonesia pada Siswa Kelas X SMK Yaperjasa.

\section{B. KAJIAN TEORI}

\section{Hakikat Minat Membaca}

Minat (interest) berarti kecenderungan dan kegairahan yang tinggi atau keinginan yang besar terhadap sesuatu (Syah, 2010: 133). Kecenderungan dan kegairahan yang tinggi tentunya akan mengakibatkan seseorang lebih bersemangat dalam melakukan sesuatu. Apabila seseorang memiliki keinginan yang kuat untuk melakukan pekerjaan atau suatu hal maka orang tersebut dikatakan memiliki minat terhadap pekerjaan atau hal terkait.

Slameto (2010: 180) menyatakan bahwa minat adalah suatu rasa lebih suka dan rasa ketertarikan pada suatu hal atau aktivitas, tanpa ada yang menyuruh. Seseorang yang memiliki ketertarikan terhadap suatu hal maka ia akan melakukan pekerjaannya dengan lebih senang dan tanpa paksaan dari orang lain. Minat pada dasarnya adalah penerimaan akan suatu hubungan antara diri sendiri dengan sesuatu di luar diri. Semakin kuat atau dekat hubungan tersebut, semakin besar minat terhadap hal yang ingin dilakukan.

Minat seringkali dikaitkan dengan faktor-faktor internal lainnya seperti: pemusatan perhatian, keingintahuan, motivasi, dan kebutuhan. Ketertarikan siswa dalam membaca dapat memengaruhi kualitas pencapaian hasil belajar siswa dalam bidang-bidang studi tertentu. Siswa yang memiliki ketertarikan lebih terhadap suatu pelajaran, maka hasil belajarnya pun akan lebih memuaskan. Namun, sebaliknya apabila siswa tidak memiliki minat terhadap suatu pelajaran, maka hasil belajarnya pun tidak akan memuaskan. Hasil belajar siswa juga dipengaruhi oleh kemampuan membaca pemahaman.

Membaca merupakan kegiatan interaksi antara pembaca dan penulis. Melalui membaca, seseorang akan menerima banyak hal tentang pengetahuan maupun informasi yang sifatnya menghibur. Tarigan (2008: 7) mengemukakan bahwa "membaca adalah suatu 
proses yang dilakukan serta dipergunakan oleh pembaca untuk memperoleh pesan, yang hendak disampaikan oleh penulis melalui media kata-kata/ bahasa tulis". Pada saat membaca, pembaca memanfaatkan waktu untuk mendapatkan maksud yang terdapat pada suatu bacaan. Pembaca harus memahami maksud yang disampaikan penulis melalui bahasa tulis.

Soedarso (2004: 4) menyebutkan bahwa membaca adalah aktivitas yang kompleks dengan mengerahkan sejumlah besar tindakan yang terpisah-pisah yang meliputi orang harus menggunakan pengertian dan khayalan, mengamati, dan mengingat-ingat. Artinya, pembaca harus melakukan beberapa aktivitas dalam proses membaca agar memperoleh pemahaman terhadap isi bacaan.

Irwansyah dan Mukhtar (2013: 10) menyebutkan ada lima manfaat yang dapat dipetik dari membaca. Pertama, menemukan sejumlah informasi dan pengetahuan yang sangat berguna dalam praktik hidup sehari-hari. Kedua, berkomunikasi dengan pemikiran, pesan, dan kesan pemikir-pemikir kenamaan dari segala penjuru dunia. Ketiga, mengikuti perkembangan ilmu pengetahuan dan teknologi mutakhir dunia. Keempat, mengetahui peristiwa besar dalam sejarah, peradaban, dan kebudayaan suatu bangsa. Kelima, memecahkan berbagai masalah kehidupan dan mengantarkan seseorang menjadi pandai.

Berdasarkan uraian tentang manfaat membaca dapat disimpulkan bahwa kegiatan membaca memiliki dampak yang sangat baik bagi seseorang. Pembaca dapat memperoleh informasi-informasi, meningkatkan daya nalar, mengikuti perkembangan zaman dan teknologi, dan dapat memecahkan berbagai masalah kehidupan. Seorang siswa dalam membaca dipengaruhi juga oleh minatnya atau yang disebut dengan minat membaca.

Minat membaca merupakan ketertarikan seseorang terhadap kegiatan membaca. Kegiatan membaca seseorang biasanya dibentuk oleh minat yang akan menghasilkan kebiasaan membaca. Menurut Tampubolon (2015: 223), "kalau minat tidak berkembang (tidak ada) maka kebiasaan membaca sudah tentu tidak akan berkembang." Seseorang akan merasa tidak tertarik saat membaca karena tidak adanya dorongan dari dalam diri. Minat seseorang untuk membaca sangat penting karena apabila tidak memiliki minat maka kegiatan membaca sulit terjadi. Walaupun kegiatan membaca terjadi maka seseorang tidak akan membaca dengan sungguh-sungguh. Kesungguhan dalam membaca sangat penting karena dapat mengakibatkan disiplin dalam diri seseorang. Kedisiplinan inilah yang akan membentuk kebiasaan membaca. 
Harjasujana (Iskandarwassid dan Sunendar, 2008: 113) mengemukakan bahwa ketiadaan minat baca dapat menimbulkan ketidakmampuan membaca; ketidakmampuan membaca dapat menimbulkan ketiadaan minat baca. Jadi, dapat dikatakan bahwa minat dan membaca saling berhubungan dengan keterampilan membaca seseorang.

Ketertarikan seseorang akan suatu hal memiliki ciri-ciri yang berkaitan satu sama lain. Pada mulanya seseorang kan menujukkan perhatian lebih terhadap suatu hal. Selanjutnya, akan menujukkan rasa senang terhadap hal tersebut. Setelah itu, akan melakukan kegemaran yang berkaitan dengan suatu hal. Setelah melakukan ketiga hal tersebut, maka siswa akan melakukan suatu hal yang merupakan bagian dari motivasi. Hal tersebut akan membawa siswa pada kepuasan setelah melakukan pekerjaan tertentu.

Berdasarkan uraian mengenai minat membaca, dapat disimpulkan bahwa minat membaca merupakan ketertarikan seseorang terhadap kegiatan membaca. Minat membaca juga bisa terbentuk dari kebiasaan membaca. Melalui kegiatan membaca yang rutin maka hal tersebut akan menjadi kebiasaan yang berdampak positif. Minat siswa dalam membaca akan membawa kepuasan bagi siswa itu sendiri.

\section{Hakikat Kemampuan Membaca Pemahaman}

Menurut Irwansyah dan Mukhtar (2013: 42) membaca pemahaman merupakan istilah yang digunakan untuk mengidentifikasi keterampilan-keterampilan yang perlu dipahami dan menetapkan informasi yang ada dalam bahan-bahan tertulis. Pada saat membaca pemahaman terdapat tiga hal pokok yang harus diperhatikan, antara lain:

a. Pengetahuan dan pengalaman yang telah dimiliki tentang topik;

b. Menghubungkan pengetahuan dan pengalaman dengan teks yang akan dibaca, dan

c. Proses memperoleh makna secara aktif sesuai dengan pandangan yang dimiliki.

Ketiga hal pokok dalam membaca pemahaman harus diperhatikan karena pengetahuan dan pengalaman pembaca tentunya akan memengaruhi makna yang dapat ditangkap oleh pembaca. Jadi, dapat disimpulkan seseorang yang memiliki pengetahuan dan pengalaman yang sama atau hampir sama dengan teks yang dibaca maka akan menghubungkan pengetahuan dan pengalamannya itu terhadap isi teks bacaaan. Oleh karena itu, pembaca lebih mudah dalam memahami makna sebuat teks. 
Djiwandono (2008: 116) menguraikan bahwa dalam memahami bacaan pada dasarnya meliputi rincian kemampuan yang terdiri atas kemampuan untuk (a) memahami arti kata-kata sesuai penggunaannya dalam wacana, (b) mengenali susunan organisasi wacana dan antar hubungan bagian-bagiannya, (c) mengenali pokok-pokok pikiran yang terungkapkan, (d) mampu menjawab pertanyaan-pertanyaan yang jawabannya secara eksplisit terdapat di wacana, (e) mampu menjawab pertanyaan-pertanyaan yang jawabannya terdapat dalam wacana meskipun diungkapkan dengan kata-kata yang berbeda. Hal ini sesuai dengan pendapat Dardjowidjojo (2014:303) yang menyatakan bahwa seorang penulis tidak selamanya menyatakan sesuatu secara eksplisit. Artinya, pembaca harus dapat memahami apa yang tidak tertulis dalam bahan bacaan itu, (f) mampu menarik inferensi (simpulan) tentang isi wacana, (g) mampu mengenali dan memahami kata-kata dan ungkapan-ungkapan untuk memahami nuansa sastra, (h) mampu mengenali dan memahami maksud dan pesan penulis sebagai bagian dari pemahaman tentang penulis. Rincian-rincian kemampuan tersebut dapat digunakan oleh guru sebagai landasan atau batasan-batasan dalam membuat tes kemampuan membaca pemahaman.

Kemampuan membaca pemahaman siswa sangat berkaitan dengan pelajaran bahasa Indonesia. Pemahaman siswa terhadap suatu bacaan dapat diukur atau dinilai melalui berbagai macam materi pelajaran dalam mata pelajaran bahasa Indonesia. Guru dapat melakukan penilaian atau tes kemampuan membaca pemahaman siswa dengan menyajikan wacana atau karangan baik karangan fiktif maupun nonfiktif. Kunarto (2011: 276) menyebutkan beberapa teknik penyajian karangan populer yaitu teknik penyajian narasi, deskripsi, eksposisi, persuasi, dan argumentasi. Wacana atau karangan-karangan tersebut dapat digunakan untuk tes pemahaman bacaan siswa.

\section{METODE PENELITIAN}

Penelitian ini merupakan penelitian korelasional dengan metode survei. Menurut Syamsuddin (2015: 25) penelitian korelasional berhubungan dengan penilaian hubungan antara dua atau lebih fenomena. Peneliti memberikan angket minat membaca dan mengadakan tes untuk mengetahui kemampuan membaca pemahaman siswa. Pendekatan yang digunakan adalah pendekatan kuantitatif.

Pendekatan kuantitatif digunakan untuk mengukur variabel bebas dan variabel terikat dengan menggunakan data penelitian berupa angka-angka yang dianalisis menggunakan 
statistik. Variabel yang memengaruhi atau yang menjadi sebab perubahannya atau timbulnya variabel terikat disebut variabel bebas. Sedangkan variabel terikat merupakan variabel yang dipengaruhi atau yang menjadi akibat karena adanya variabel bebas (Sugiyono, 2016: 39). Variabel bebas penelitian ini adalah minat membaca sedangkan variabel terikatnya adalah kemampuan membaca pemahaman.Teknik sampling yang digunakan dalam penelitian ini adalah simple random sampling yang termasuk dalam probability sampling karena memberikan peluang yang sama bagi setiap unsur (anggota) populasi untuk dipilih menjadi anggota sampel. Peneliti memilih menggunakan teknik simple random sampling (teknik acak sederhana) karena pengambilan anggota sampel dari populasi dilakukan secara acak tanpa memperhatikan strata atau kedudukan yang ada dalam populasi itu.

Peneliti menentukan sampel 34\% dari jumlah siswa. Sampel yang ditentukan 34\% dari 147 siswa yaitu 50 siswa. Pengumpulan data yang digunakan untuk mengetahui minat membaca siswa adalah dengan menggunakan angket atau kuesioner. Angket dalam penelitian ini digunakan untuk mengetahui, menganalisis, dan menginterpretasikan hubungan minat belajar terhadap hasil belajar bahasa Indonesia dengan menggunakan variabel minat belajar. Pertanyaan yang diajukan dalam angket penelitian ini berjumlah 40 pertanyaan dan berbentuk skala Likert.

Pengumpulan data untuk mengetahui kemampuan membaca pemahaman mata pelajaran Bahasa Indonesia adalah dengan melalui tes. Jumlah soal tes yang digunakan dalam penelitian ini adalah 40 butir soal dengan bentuk tes objektif yaitu pilihan ganda.

\section{HASIL DAN PEMBAHASAN}

Minat membaca merupakan ketertarikan seseorang terhadap kegiatan membaca. Minat membaca juga bisa terbentuk dari kebiasaan membaca. Melalui kegiatan membaca yang rutin maka hal tersebut akan menjadi kebiasaan yang berdampak positif. Minat siswa dalam membaca akan membawa kepuasan bagi siswa itu sendiri.

Kemampuan membaca pemahaman merupakan kemampuan seseorang dalam memahami isi atau maksud dari sebuah wacana tulis. Membaca pemahaman terdiri dari pemahaman literal, interpretasi, kritis, dan kreatif. Kemampuan tersebut meliputi kemampuan untuk (a) mengenali susunan organisasi wacana dan antar hubungan bagianbagiannya, (b) mengenali pokok-pokok pikiran yang terungkapkan, (c) mampu menjawab pertanyaan-pertanyaan yang jawabannya secara eksplisit terdapat di wacana, (d) mampu 
menjawab pertanyaan-pertanyaan yang jawabannya terdapat dalam wacana meskipun diungkapkan dengan kata-kata yang berbeda, (e) mampu menarik inferensi (simpulan) tentang isi wacana.

Berdasarkan perhitungan pada uji normalitas data minat membaca dan tes kemampuan membaca pemahaman menunjukkan bahwa kedua data berdistribusi normal. Data minat membaca berdistribusi normal karena nilai [ $\left.\mathrm{x}^{\wedge} 2\right]$ _hitung $<\llbracket \mathrm{x}^{\wedge} 2 \rrbracket$ _tabel $(4,751<$ 9,49). Sedangkan, data kemampuan membaca pemahaman berdistribusi normal karena $(7,482<9,49)$.

Data yang dinyatakan berdistribusi normal kemudian diuji melalui uji linearitas. Uji linearitas diperlukan untuk mengetahui apakah metode regresi Y yaitu tes kemampuan membaca pemahaman dengan $X$ (minat membaca) berpola linear atau tidak.

Berikut frekuensi data minat membaca dan kemampuan membaca pemahaman:

\section{Gambar 1 Histogram Data Variabel Minat Membaca}

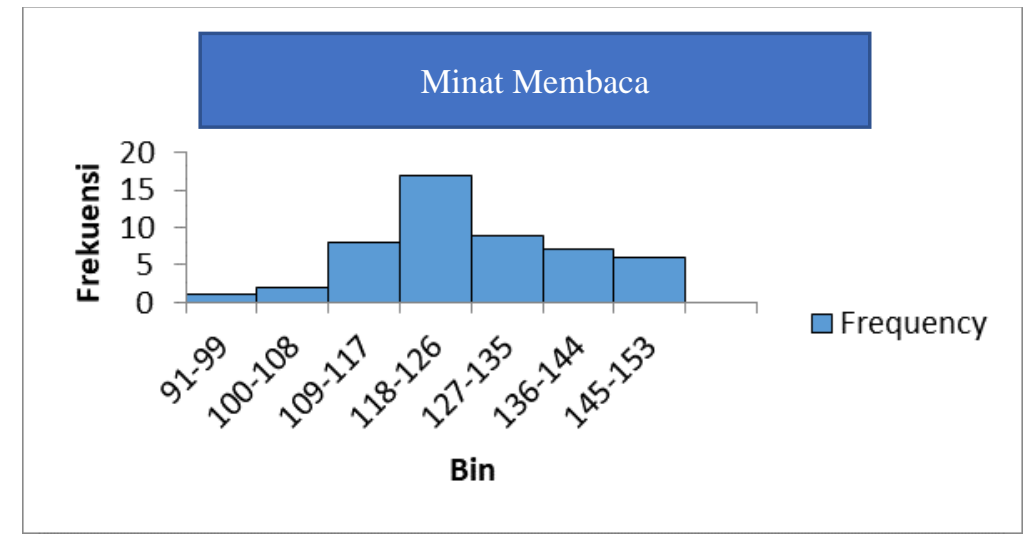

Berdasarkan data variabel minat membaca, diperoleh skor tertinggi sebesar 153 dan skor terkecil sebesar 93. Harga Mean sebesar 126,68. Modus atau nilai yang paling sering muncul adalah 122,26. Nilai tengah atau median adalah 124,91. Standar Deviasi atau simpangan baku yang diperoleh adalah 13,01. Sedangkan untuk varians sebesar 169,26. 


\section{Gambar 2 Histogram Data Variabel Kemampuan Membaca Pemahaman}

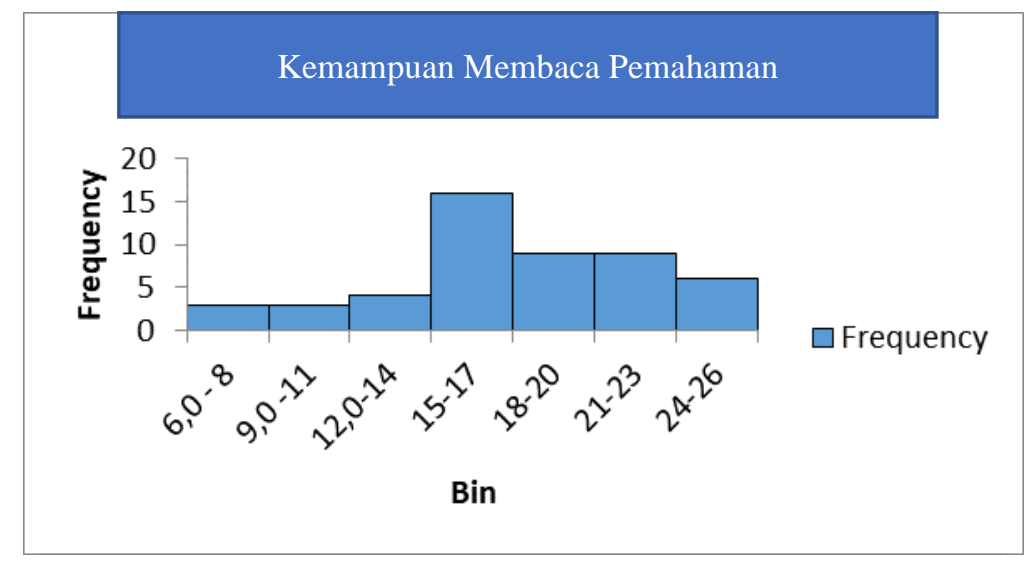

Berdasarkan data variabel hasil tes kemampuan membaca pemahaman, diperoleh skor tertinggi sebesar 26 dan skor terkecil sebesar 6. Harga Mean sebesar 17,56. Modus atau nilai yang paling sering muncul adalah 16,39. Nilai tengah atau median adalah 17,31. Standar Deviasi atau simpangan baku yang diperoleh adalah 4,85. Sedangkan untuk varians sebesar 23,52.

Berdasarkan perhitungan, didapatkan hasil $\mathrm{F}_{\text {_ hitung }} \leq \mathrm{F}$ _tabel $(1,76 \leq 2,14)$ maka Ho diterima berarti linear. Hasil tersebut menunjukkan bahwa metode regresi $\mathrm{Y}$ (tes kemampuan membaca pemahaman) atas $\mathrm{X}$ (minat membaca) yang telah dilakukan di kelas X SMK Yaperjasa berpola linear.

Selain itu, dilakukan pengujian hipotesis melalui uji korelasi Pearson Product Moment, uji determinasi, dan uji signifikansi. Berdasarkan perhitungan uji korelasi Pearson Product Moment didapatkan koefisien korelasi sebesar 0,48. Jadi, dapat disimpulkan bahwa terdapat hubungan antara minat membaca dengan kemampuan membaca pemahaman mata pelajaran Bahasa Indonesia dengan tingkat korelasi sedang.

Langkah selanjutnya adalah uji determinasi. Hasil dari uji determinasi menunjukkan bahwa pengaruh nilai minat membaca terhadap kemampuan membaca pemahaman sebesar 23\% dan sisanya 77\% dipengaruhi oleh variabel lain. 
Selanjutnya, dilakukan uji signifikansi. Uji signifikansi data minat membaca dan kemampuan membaca pemahaman siswa kelas X SMK Yaperjasa bertujuan untuk mengetahui apakah kedua data yang dikumpulkan signifikan atau tidak.

Hasil uji signifikansi menunjukkan bahwa hubungan minat membaca dengan kemampuan membaca pemahaman siswa kelas X SMK Yaperjasa siginifikan karena t_hitung $\geq \mathrm{t}$-tabel atau $4,31 \geq 1,677$. Hal ini menyatakan bahwa Ho diterima. Artinya, terdapat hubungan yang positif antara minat membaca dengan kemampuan membaca pemahaman siswa kelas X SMK Yaperjasa khususnya pada mata pelajaran Bahasa Indonesia.

Berdasarkan hasil penelitian dapat dibuktikan bahwa minat membaca membaca saling berhubungan dengan kemampuan membaca pemahaman siswa. Hasill penelitian ini sesuai dengan penelitian yang pernah dilakukan sebelumnya bahwa ada hubungan signifikan atau minat membaca benar-benar berpengaruh dengan hasil belajar bahasa Indonesia siswa. Jadi, minat membaca siswa sangat berpengaruh terhadap kemampuan membaca siswa kelas X SMK Yaperjasa khususnya pada mata pelajaran Bahasa Indonesia.

\section{E. KESIMPULAN}

Minat membaca dan kemampuan membaca pemahaman merupakan kedua hal yang saling berhubungan. Peneliti telah melakukan penelitian di SMK Yaperjasa pada siswa kelas X SMK Yaperjasa. Berdasarkan hasil analisis dan pembahasan, maka dapat disimpulkan terdapat hubungan positif dengan koefisien korelasi sebesar 0,48 antara minat membaca dengan kemampuan membaca pemahaman mata pelajaran Bahasa Indonesia siswa kelas X SMK Yaperjasa dengan tingkat korelasi sedang. Hubungan antara minat membaca dengan kemampuan membaca pemahaman mata pelajaran Bahasa Indonesia siswa kelas X SMK Yaperjasa juga signifikan karena t_hitung > t_tabel dengan t_hitung=4,3 dan t_tabel $=1,677$.

\section{F. SARAN}

Berdasakan hasil analisis dan simpulan yang telah diuraikan maka dapat diberikan beberapa saran. Penelitian selanjutnya diharapkan dapat mengembangkan krativitas dan inovasi metode pembelajaran yang dapat menumbuhkan minat 
membaca siswa. penelitian selanjutkan juga diharapkan dapat menemukan cara agar minat membaca siswa meningkat. Selain itu, diharapkan juga adanya metode kreatif agar kemampuan membaca pemahaman siswa bagus. Apabila minat membaca siswa tinggi maka diharapkan dapat meningkatkan kemampuan membaca pemahaman siswa.

\section{DAFTAR PUSTAKA}

Dardjowidjojo, Soenjono, 2014, Psikolinguistik, Pengantar Pemahaman Bahasa Manusia, Jakarta, Yayasan Pustaka Obor Indonesia.

Djiwandono, Soenardi, 2008, Tes Bahasa Pegangan bagi Pengajar Bahasa, Jakarta, PT Indeks.

Irwansyah, Nur dan Mukhtar, 2013, Buku Mata Kuliah Membaca, Tangerang, Pustaka Mandiri.

Iskandarwassid dan Dadang Sunendar, 2008, Strategi Pembelajaran Bahasa, Bandung, PT Remaja Rosdakarya

Kunarto, Niknik M, 2011, Cermat dalam Berbahasa Teliti dalam Berpikir, Jakarta, Mitra Wacana Media.

Slameto, 2010, Belajar dan Faktor-Faktor yang Mempengaruhinya, Jakarta, Rineka Cipta.

Soedarso, 2004, Speed Reading Sistem Membaca Cepat dan Efektif, Jakarta, Gramedia Pustaka Utama.

Syah, Muhibbin, 2010, Psikologi Pendidikan dengan Pendekatan Baru, Bandung, PT Remaja Rosdakarya.

Syamsuddin dan Vismaia S, Damaianti, 2015, Metode Penelitian Pendidikan Bahasa, Bandung, PT Remaja Rosdakarya.

Sugiyono, 2016, Metode Penelitian Kuantitatif, Kualitatif, dan R\&D, Bandung, Alfabeta.

Tampubolon, 2015, Kemampuan Membaca, Teknik Membaca Efektif dan Efisien, Bandung, Angkasa

Tarigan, Henry Guntur, 2008, Membaca, Sebagai Suatu Keterampilan Berbahasa, Bandung, Angkasa. 